Ankara University Journal of Faculty of Educational Sciences

Year: 2021, Volume: 54, Issue: 3, 863-890

DOI: 10.30964/auebfd.899015, E-ISSN: 2458-8342, P-ISSN: 1301-3718

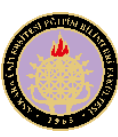

\title{
High-Achieving Adults' Opinions on Their Educational Lives and Suggestions About Educating Gifted Students ${ }^{1}$
}

\begin{tabular}{lccc}
\hline ARTICLE TYPE & Received Date & Accepted Date & Published Date \\
Research Article & 03.18 .2021 & 11.18 .2021 & 11.30 .2021 \\
\hline
\end{tabular}

\author{
Abdul Samet Demirkaya (iD ${ }^{2}$ \\ Burdur Mehmet Akif Ersoy University \\ Özlenen Özdiyar Gedik (D) ${ }^{3}$ and Eda Gürlen (iD ${ }^{4}$ \\ Hacettepe University
}

\begin{abstract}
The purpose of this study is to infer suggestions to improve the quality of educational services provided to gifted students based on the high-achieving adults' educational experiences and opinions. High-achieving adults reflected on their school experiences, the problems they faced with and their struggles as students, and they stated their suggestions related to the educational services that should be provided to gifted students. The research data were gathered through phenomenological design. The study group was composed of eight high-achieving individuals from Turkey. The data were gathered through semi-structured interview forms. The content analysis method was used to analyze the data of the study. High-achieving adults stated that they were not provided with the required support and guidance from their administrators, teachers, families, and environments in order to realize their potentials. They suggested that the instruction should be differentiated through the individual needs of gifted students, and varied instructional methods should be used in order to sustain the multi-faceted development of gifted students.
\end{abstract}

Keywords: Gifted education, high-achieving adult, gifted student, educational needs, gifted students' problems.

Ethical committee approval: The ethical committee approval was obtained from Hacettepe University Ethical Committee, No: 76942594-900/2774, Date: 03.08.2015.

\footnotetext{
${ }^{1}$ This article is one of the conducted studies within SAY-2015-5069 Hacettepe University Scientific Research Projects Coordination Unit "Elementary School (K1-K4) Curriculum Development Project for Gifted Students: An Action Research" and a part of this article was presented as an oral presentation under the name of "Gifted adults' opinions on their educational lives and recommendations on gifted education" at the International Talented and Gifted Conference, May 4-6, 2017.

${ }^{2}$ Corresponding Author: Research Assistant, Faculty of Education, Department of Educational Sciences, Burdur, Turkey, e-mail: sdemirkaya @mehmetakif.edu.tr, https://orcid.org/0000-0001-6704-3898

${ }^{3}$ Research Assistant, Faculty of Education, Department of Educational Sciences, Ankara, Turkey, e-mail: ozlenen@ hacettepe.edu.tr, https://orcid.org/0000-0001-5804-6384

${ }^{4}$ Prof. Dr., Faculty of Education, Department of Educational Sciences, Ankara, Turkey, e-mail: edaerdem@hacettepe.edu.tr, https://orcid.org/0000-0002-1719-9840
} 
Gifted people differ from their peers in terms of their ability to learn fast and to reflect upon issues that other people can only understand shallowly (Gallagher, 1997). These people may have qualities such as creativity, curiosity, authenticity, skillfulness, and will to question order and tradition (Renzulli, 2012). The world will always need gifted, well-educated and compassionate people who can take responsibility for themselves as well as others and discharge this responsibility (Freeman, 2001). Because of this reason, the high potential owned by these people is of great importance both for themselves and for society.

The prior aim of gifted education is to maintain that young people can realize themselves by giving opportunity to these people to present their improvement and performance in one or more areas where they have a high potential. The second aim is to increase the number of people that can solve the problems of modern civilization through producing new knowledge and art instead of only using the existing knowledge (Renzulli, 2012). In line with these aims, gifted students should be ensured with the necessary opportunities and settings. According to Clark (1997), having equal opportunities does not mean having the same opportunities, but it means having the appropriate experiences suitable for each individual. No matter which skills, interests, or abilities an individual has, each individual needs to have all opportunities in hand to improve to the most. When the issue is considered for Turkey, the necessary educational policies and practices should be implemented to ensure that gifted students with high potentials make the most use of their educational lives and to turn themselves into individuals who produce knowledge and contribute to the development of society.

Practices for the education of gifted students continue to develop around the world and many countries' attention on gifted education is increasing (Koshy, Smith and Casey, 2018; Kronborg, 2018; Reid, 2015). The researches in the field display that acceleration, enrichment and differentiation practices used in educational services for gifted students, have increased the academic achievement of gifted students (Colangelo, Assouline and Gross, 2004; Lee, Olszewski-Kubilius and Peternel, 2010; Umar and Reis, 2014). Therefore, educating high potentials is gaining importance day by day in Turkey as well, educational services and researches in the field are increasing aligned with public awareness in gifted education, and the issue of educating gifted people is taken as one of the prior considerations in educational policies and reforms (Sak, Ayas, Sezerel, Öpengin, Özdemir and Gürbüz, 2015). The educational practices for gifted students in Turkey are being taken into consideration in terms of national strategy, equality in education, and child rights, and different educational practices, such as differentiation, acceleration and enrichment opportunities are provided to gifted students. The schools provide several educational practices to gifted students through private classes, individual arrangements in the regular classrooms, or extracurricular activities designed for gifted students (The Grand National Assembly of Turkey, 2012). However, negative attitudes toward the education of gifted students, inefficient policies and educational opportunities, and lack of curriculums stand as problems of the field for Turkey (Sak et al., 2015). 
Defects in the identification of gifted students continue. The lack of flexibility in the educational system restrain acceleration practices, and the inadequacy of resource rooms negatively affects many gifted students (Çitil, 2018). So, it can be told that necessary educational policies and practices should be developed in order to supply gifted students with more qualified educational services.

The opinions and suggestions presented by the shareholders of education are of great importance to identify the gaps and problems of the field and to create more efficient educational services for gifted students. In the literature, the opinions of administrators, families, teachers and students about educating gifted students are presented in various researches (Hertzog, 2003; Hertzog and Bennett, 2004; Swanson, 1997; Szymanski and Shaff, 2013; Young and Balli, 2014). Terman in his longitudinal studies with gifted adults displayed how giftedness affect adult life and revealed that gifted adults were high achievers in school, in their occupations and activities, and they demonstrated superiority in their life (Hastorf, 1997). There is a growing interest in understanding gifted adults in the field (Brown, Peterson and Rawlinson, 2020). However, in the process of developing and implementing education policies for gifted students, researches in which, high achieving adults are asked about their opinions and suggestions are very limited. High-achieving adults, who have completed formal education, constitute a vital source of information as a result of their experiences of the educational system, school environment, curriculum, and learning practices they were subject to as a student, so their reflections offer opportunities to make gifted education better. Therefore, the aim of this study is to present some suggestions in terms of improving the quality of educational services rendered to gifted students, based on the high-achieving adults' opinions about their educational lives and the problems they faced with. Aligned with this aim, high-achieving adults were asked their opinions about their educational lives and the level of fulfillment of their educational needs and expectations as well as suggestions related to the educational services that should be provided to gifted students. It is expected that the results of this study will contribute to the improvement of the quality of the educational services presented to gifted students, and based on the findings, the awareness about the problems faced by this group of special students during their educational lives might increase.

\section{Method}

Research design, study group, data collection tools and data analysis are presented under this heading.

\section{Research Design}

The data used in this study were gathered through phenomenological design. Phenomenological researches give the opportunity to perceive and understand a determined phenomenon and to reach detailed explanations, examples and experiences related to this phenomenon (Patton, 1990; Yıldırım and Şimşek, 2011). 


\section{Study Group}

The snowball sampling method is used to determine the study group of the research which is a commonly used purposeful sampling method, and advantageous to find participants fitting the criteria of the research (Patton, 1990). In order to determine the high-achieving adults to be included in the study, the researchers reached the related institutions (Turkish Intelligence Foundation, etc.) and experts. Giftedness, academic success and career success were used as criteria in the selection of individuals to be included in the study group. Institutions and experts conveyed that due to insufficient identification services in Turkey in the past, many gifted students were not identified, so it is difficult to reach identified gifted adults of today. They recommended a total of 8 gifted individuals who met the criteria as diagnosed and undiagnosed gifted individuals. In order to refer to the study group "high-achieving adults" term is used, since it is composed of both identified and unidentified gifted adults. The study group was composed of eight gifted individuals who were between the ages of 24 and 60 from Turkey. Two of the eight participants were living in rural areas, six of them were living in cities among two were living in metropoles as students. The participants' socioeconomic status was low except for one of them. Two of the eight participants were academicians working at the top-ranked Turkish universities, two of them were expert physicians, one of them was an engineer working at a reputable defense electronics company, one of them was a uniquely talented musician, one of them was a referee of Mathematics in Intelligence Olympiads and one of them was a multifaceted person who was an author, former politician and member of parliament and current administrator at an association.

\section{Data Collection Tools}

Yıldırım and Şimşek (2011) state that the prior data-gathering tool in phenomenological researches is the interview. The purpose of interviewing is to figure out the opinions, perceptions, feelings, attitudes, and values of people (Fraenkel and Wallen, 2003). The data in this study were gathered through semi-structured interview forms. While preparing the questions included in the interview, statements that would not direct the participants were chosen; clear and understandable open-ended questions were used. Six open-ended interview questions aimed to reveal the participants' educational experiences, whether their educational needs were met, the impact of the school on their success, their relations with the stakeholders of education, and the education of gifted education. In order to determine the validity of the interview form, seven experts in their fields, three of whom were experts in Assessment and Evaluation, three of whom were experts in Curriculum and Instruction, and finally one of whom was an expert in Psychological Counselling and Guidance were asked about their expert opinions. In line with the views of the experts, minor conceptual changes were executed on the interview form.

The interviews were made by two researchers between March 2016 and March 2017. The interviews lasted between 40 and 60 minutes. In order to increase the validity and reliability of the study, the interviews were made face to face at places 
demanded by the participants, and the acquired interview data were confirmed by the participants. In order to ensure the credibility and transferability of the study, interviews were recorded, audio records were transferred to computer, transcribed, and reported in detail. The participants were coded as P1-P8.

\section{Data Analysis}

In phenomenological researches, data analysis is done to reveal experiences and meanings (Y1ldırım and Şimşek, 2011). The content analysis method, which is a qualitative research method, was used to analyze the data gathered for this study. According to Fraenkel and Wallen (2003) content analysis is a method used in revealing people's ideas, attitudes and values mostly in written contents of a communication. Three researchers analyzed the data individually four times each in order to ensure researcher triangulation and increase the dependability, and determined codes, sub-themes and themes to describe problems faced by gifted people during their educational lives and their suggestions to improve the quality of gifted education. Codes are decided based on the analysis of the statements, and common meaningful units. Sub-themes are derived from codes based on the generated code categories and defined with the best fitting terms. Themes are generated problem-oriented and context-based. Categorical connections are used in gathering sub-themes under the themes. Descriptive direct quotations of the participants are used in the research. The consistency between coders is calculated based on the Miles and Huberman reliability formula and the percentage of agreement between the coders is found as $87 \%$. Agreement percentage above $70 \%$ is considered as an adequate reliability value (Miles and Huberman, 1994).

\section{Results}

When the findings were analyzed, seven themes of problems were determined, which are problems faced during teaching and learning processes, problems caused by educational system/policies, teachers, administrators, other students, family and society, and self-attributes. Another theme was determined related to the expectations and suggestions of high-achieving adults about gifted education.

\section{Problems Resulting from Educational System/Educational Policies}

It has been determined that there are various problems resulting from educational system/educational policies according to high-achieving adults. The theme and subthemes related to these problems are given in Table 1.

Table 1

Problems resulting from educational system/educational policies

\begin{tabular}{ll}
\hline Theme & Sub-themes \\
\hline Problems resulting from & Insufficiency of opportunities \\
educational system / & The effect of teachers employment policies \\
educational policies & The negative effect of examinations \\
& $\begin{array}{l}\text { Non-existence of formal curriculum for gifted students } \\
\text { The expectations of educational shareholders from students }\end{array}$ \\
\hline
\end{tabular}


According to Table 1, among the problems resulting from educational system/educational policies, the most eye-catching one is the insufficiency of opportunities.

"The limitations, time loss and impossibilities caused by the insufficiencies at schools had a negative effect on my success. If the level of education had been medium at least, I would have participated in Mathematics, Physics and Computer Olympics, which I even heard after entering METU (Middle East Technical University) or I would have produced TUBITAK (Scientific and Technological Research Council of Turkey) projects.” P3

"I started primary school at a school with limited opportunities. I think the educational life of the student is affected to a great extent by this period when the student gets accustomed to the teacher and an attachment between them is established. Moreover, it was this period, which was a bit hard for me. Teachers were changing so often. I had five different teachers in grade 1 of the primary school.” P5

High-achieving adults stated that they had faced problems such as the quantitative insufficiency of teachers, non-existence of teachers in some disciplines and the frequent change of teachers during the year.

"I attended Chemistry 1 class, but there were not any teachers to teach Chemistry 2 and 3. Therefore, I attended the Countries' Geography lesson instead. The same teacher was teaching History, Geography and Physical Education." P3

"The teachers teaching Biology were paid teachers, so Biology teachers used to change every semester." P8

High-achieving adults made some criticism about the negative effects of focusing on examinations too much in the educational system.

"In our country, success is assessed through exams that start as soon as students learn how to read and write, and most of the time, these exams last for the rest of life at various levels in a lifespan. As a result, such a success mold has been determined and people are directed and shaped into this mold." P5

High-achieving adults emphasized some problems such as the non-existence of curriculum designed for gifted students at state schools and the insufficiency of the existing curriculum to meet the needs while they stated that they could not make use of extra educational services such as Science and Art Centers.

"There is no special curriculum for gifted students at state schools. The curriculum for all students is also valid for us. Because of this reason, my family played an important role in my educational experience.” P7 
"For instance, there are schools such as Science and Art Centers now. There were no such schools in our time. I would have attended that school instead of going to private courses." P2

High-achieving adults criticized the expectations of educational shareholders from the students and their perceptions about success.

"I personally think most schools and the adopted classical methods of education annihilate the creativity of students. Most of the time, the students are expected to listen to the teacher carefully at school, be quiet, stay away from opposing, do tons of homework, spend most of the time on studying. The students are accepted to be hard-working if they reflect this portrait otherwise they are considered lazy." P5

When the opinions of high-achieving adults are examined, it is apparent that problems resulting from educational life and educational policies such as insufficient opportunities, non-existence of curriculum designed for gifted students, and unplanned employment of teachers.

\section{Problems Faced During Teaching-Learning Processes}

It has been determined that high-achieving adults faced problems during teaching and learning processes. The themes and sub-themes related to these problems are presented in Table 2.

\section{Table 2}

Problems faced during teaching-learning processes

\begin{tabular}{ll}
\hline Theme & Sub-themes \\
\hline Problems faced during & Ignoring the interests and needs of gifted students \\
teaching and learning & Not differentiating instruction \\
processes & Not supporting creativity \\
& Not presenting learning opportunities at a critical period \\
& Not using different methods and techniques \\
& Giving excessive responsibilities to students \\
& Crowded classes \\
& Limited interaction between students \\
\hline
\end{tabular}

When Table 2 is examined, it has been revealed that the most common problems faced by gifted students in teaching-learning processes are due to being forced to comply with the class level and their needs and intererests to be ignored by their teachers.

"I was so bored in the first three years of my school life. I learned how to read and write without doing any line drawing practices. It was too boring for me to sit still at the same place for 40 minutes. Because of this reason, my teacher 
sometimes let me go out and walk around the school. There were times when I walked around the school five times a day." P7

"There were a lot of students in our class who learned how to read and write very late. The teacher could not spare time for us because he was busy with them all the time. I used to get bored during the lessons." P5

High-achieving adults underlined the fact that they had had problems, as they could not come across any differentiation practices designed for their needs during their educational lives.

"I can never learn something to the fullest by means of listening to it. In fact, I cannot listen to someone for a long time. However, others might learn better by listening... I think that teachers can try to know the students better as they will be together for the next few years. They can try to understand in which areas they are more skillful and thus, they can support the students' strengths and weaknesses." P5

High-achieving adults stated that their teachers had not used different methods and techniques and that the practices had not changed even though the importance of this issue had been emphasized.

"Everyone says that the recitation method is not good. However, unfortunately, an approach that would eradicate this and foster differences, creativity and innovation is not adopted." P1

High-achieving adults emphasize that they have limited opportunities for interaction with teachers and other students as learning environments are insufficient and classes are crowded.

"When I was in fifth grade, administrators combined three classes to form two classes because of the insufficiency of classrooms. Now there were 50 students in one class. Therefore, it got more difficult for me to have the teacher hear me and learn something in that class." P5

High-achieving adults stated that they had had problems during their educational lives as a result of the fact that their interests and needs were ignored, their creativity was not supported, educational services rendered to the students were designed for the medium level in class and so they were ignored, and the differentiation practices they needed were not realized.

\section{Problems Resulting from Teachers}

At the end of the interview made with high-achieving adults, it became clear that there were many problems resulting from teachers. Theme and sub-themes related to these problems are given in Table 3. 
Table 3

Problems resulting from teachers

\begin{tabular}{ll}
\hline Theme & Sub-themes \\
\hline Problems resulting from & Competencies of teachers not being at the desired level \\
teachers & Uncaring attitude towards profession and students \\
& Damaging the academic self-confidence of students \\
& Not maintaining students with the guidance services \\
& Not being able to act justly \\
& Making positive discrimination \\
& Insufficient technology usage \\
\hline
\end{tabular}

High-achieving adults stated that they had had many problems during their educational lives resulting from their teachers. The most emphasized one among all is that the competencies of teachers are not at the demanded level and teachers also have an uncaring attitude towards their profession and students.

"Although some of our teachers fulfilled our expectations, I mostly had teachers who could not improve themselves, were too lazy to enrich their fund of knowledge. Thinking that you know better than the teacher, even though it is not the case, makes you stay away from that subject." P4

"It is a common problem for gifted students like us to be limited by teachers who are not sufficient in terms of knowledge and social skills." P3

"Most of our teachers were not qualified enough to meet our educational needs and interests. Some of them were quite old teachers who were close to innovation and they were teaching through the same way and the same method." P5

"For instance, some teachers pull the student back. In my opinion, uninterested teachers or the teachers who do not have any affection or love towards students, cause students to have a negative attitude towards that lesson." P8

"The teachers could not meet my needs. They could not spare time for me as I was different from the other students in class. So, my father used to bring me some CDs that were about my lessons. My educational life went in that way most of the time." P7

One of the interviewees stated that she suffered from negative attitudes of the teachers, which might damage his/her, academic self-confidence.

"There was an exam in the province I was living. There were 100 questions in the exam and I had 98 correct answers besides two wrong answers. I was expecting to rank first in the exam as I had two wrongs. But one of my teachers said, 'There are a lot of hard-working students in the province. They certainly must have done better. Do you really think that your result will be better than 
theirs?' and damaged my self-confidence. However, the teacher was not right when the results were announced." P5

High-achieving adults stated that the teachers also could not meet their needs in terms of guidance services.

"None of my teachers or school administrators could meet my expectations in terms of directing and guiding us socially and artistically." P4

"I wish I had not received a report in order not to attend physical education lesson. I wish I had been told, 'Do not receive a report. It is OK if you do not do this, but you had better do that." P1

High-achieving adults emphasized with various examples that teachers acted with positive discrimination towards gifted students.

"Since the teachers acted positively towards hardworking students, they used to do things for students who they thought could understand easily." P2

When the opinions of high achieving adults were examined, it was concluded that teachers did not have enough knowledge and skills about attributes and needs of gifted students as well as educating and guiding them, and they had uncaring attitudes towards their profession and students. In addition, some teachers discriminated against some students while they also had some behaviours that would damage students' self-confidence.

\section{Problems Resulting from Administrators}

According to high-achieving adults, administrators caused various problems. Themes and sub-themes related to this problem are given in Table 4.

Table 4

Problems resulting from administrators

\begin{tabular}{ll}
\hline Theme & Sub-themes \\
\hline Problems resulting from & Being close to interaction and communication / Highly \\
administrators & authoritative attitude \\
& $\begin{array}{l}\text { Not maintaining students with the necessary guidance } \\
\text { services }\end{array}$ \\
\hline
\end{tabular}

High-achieving adults stated that the administrators they had met were mostly highly authoritative, close to communication and were not good enough to supply them with the necessary guidance service.

"I wish our teachers and administrators had not been so highly authoritative and thus we could communicate with them more easily and comfortably." P4 
"I think administrators are not meticulous and interested enough. No matter which year it was, I think, there were some opportunities to be presented to students like me. Administrators and teachers should search for these opportunities and ensure we reach them." P3

When the opinions of high-achieving adults were examined, it came out that they faced problems about communication barriers because of the authoritative attitude displayed by the administrators and therefore they could not reach the guidance service they needed.

\section{Problems Resulting from Other Students}

High-achieving adults also had problems with other students with whom they share the same learning environment. The theme and sub-themes related to these problems are given in Table 5.

Table 5

Problems resulting from other students

\begin{tabular}{ll}
\hline Theme & Sub-themes \\
\hline Problems resulting from & The gap between the cognitive levels of students \\
other students & The effect of friendship environment \\
& Bullying \\
\hline
\end{tabular}

High-achieving adults stated that they often had problems since there was a huge gap between the cognitive levels of other students and them.

"I sometimes had serious problems with my friends, when I answered a question quickly. There were some students at secondary school, high school and university who told me not to give the correct answer in advance, and wait for them to think on the question. I had really nonsense quarrels because of this." P8

"After a while, you want to get interested in something. You want to solve some mathematics problems. There is also a difference when you do not have many friends interested in the same topics as you." P2

When the opinions of high-achieving adults were examined, it was concluded that they had problems such as being restricted to participate in the lesson, not having friends sharing the same areas of interest and bullying throughout their educational lives as there were some differences between the success levels of them and the other students with whom they shared educational environment.

\section{Problems Resulting from Family and Society}

It has been found out high-achieving adults had conflicts with their families and the society they live in. These conflicts apparently cause various problems. The theme and sub-themes related to these problems are given in Table 6. 
Table 6

Problems resulting from family and society

\begin{tabular}{|c|c|}
\hline Themes & Sub-themes \\
\hline Problems resulting from family & Not understanding the needs of their children \\
\hline Problems resulting from society & $\begin{array}{l}\text { Not having enough knowledge about gifted } \\
\text { students, their characteristics and needs } \\
\text { Expectations of the society } \\
\text { Inadequacy of role models }\end{array}$ \\
\hline
\end{tabular}

When Table 6 is examined, it is apparent that high-achieving adults had problems in their childhood as their families did not understand their needs.

"I had problems, especially at secondary school. We used to use a heating stove at home in winter. As the stove was heating one room in winter, we used to sleep in the same room. I mostly had problems with my father while I was studying and the lights were on at night. Once, we even had a serious quarrel. He even used violence against me. That was why I decided to attend boarding school." P8

It came out that the high-achieving adults had conflicts due to the fact that they could not understand the society and they were not understood by the society as well. They especially emphasized the problems they had with the families of other students.

"Sometimes, I had much higher marks in the exam than the other students. For instance, at secondary school, they demanded the exam to be cancelled. Their families wanted to cancel the exam as their children got 40 or 50 points. However, I did not want it to be cancelled as I got 95 or 100. I had problems especially because of the families of unsuccessful students as I was studying in the same class with them." P8

"I had problems to understand and to be understood in my relationships with my family and society. I was not patient and understanding enough to the society and neither was the society to me." P3

High-achieving adults stated that society was uninterested and insufficient in providing role models to gifted students.

"I did not have any acquaintances to take as a role model in my family who graduated from university. I mostly could see the teachers at school. That is why I was thinking of being a teacher. If I had met an engineer or a doctor, I could have seen what their view of life was or how they worked." P2

"The society sometimes only gets interested in if you study your lessons or not. They do not concern the improvement of your artistic or social skills." P4

When the opinions of high-achieving adults are examined, it was apparent that families and society could not understand gifted students as they did not know enough 
about gifted students' needs, characteristics and expectations. Likewise, high achieving adults had problems understanding society and meeting the expectations of society. It was also emphasized that high achieving adults could not have suitable role models in society.

\section{Problems Resulting from Self-Attributes}

According to high-achieving adults, they had some problems arising from selfattributes. The theme and sub-themes related to these problems are presented in Table 7.

Table 7

Problems resulting from self-attributes

\begin{tabular}{ll}
\hline Theme & Sub-themes \\
\hline Problems resulting from self- & Being oversensitive \\
attributes & Opposing strict rules and discipline \\
& Giving importance to the maintenance of justice \\
& Staying away from the society \\
\hline
\end{tabular}

When Table 7 is examined, it is clear that high-achieving adults had problems including staying away from society throughout their educational lives because of being oversensitive.

"I had quite many mistaken attitudes towards people and events since my point of view or criteria of evaluation were different." P3

"I had a dislike against rules and strict discipline. I was not a rebel but, I had a will to change rules without being an outlier or a rebel. Therefore, I got punishment at school a few times." P1

When the opinions of high-achieving adults are examined, it was concluded that high-achieving adults had some serious problems such as staying away from society or giving up because of troubles resulting from self-attributes. Some of the problems participants have mentioned were being oversensitive, being emotional, having a will to have justice and not standing injustice, not being able to understand strict rules, and having the will to bend the rules, and having a different evaluation criteria.

\section{Expectations and Suggestions of High-achieving Adults about the Education of Gifted Students}

Considering their own educational lives, high-achieving adults stated their expectations and suggestions about the education to be rendered to gifted students. The theme and sub-themes related to these expectations and suggestions are given in Table 8 . 
Table 8

Expectations and suggestions of gifted adults about the education of gifted students

\begin{tabular}{ll}
\hline Theme & Sub-themes \\
\hline Expectations & Providing gifted students guidance service through their interests \\
and suggestions & and needs \\
& Establishing enriched, differentiated and accelerated curriculum \\
& Improving the competencies of teachers \\
& Teachers and administrators to be open to interaction \\
& Ensuring students to gain higher order thinking skills \\
& Using technology effectively \\
& Enlightening the society about gifted children \\
\hline
\end{tabular}

When Table 8 is examined, it is clear that high-achieving adults strongly emphasize that it is necessary to determine the interests and needs of students and to present them the necessary guidance service aligned with their interests and needs.

"I wish gifted students would be directed to areas where they have a special talent, and not to be judged because of their different ideas, but instead supported." P5

"I wish the opportunities in our country and abroad would be carefully monitored, gifted students' interests, skills, knowledge and social needs would be determined, and these students would be educated at institutions that are supported by the government." P3

High-achieving adults suggested gifted students be provided educational services that would meet their needs by means of establishing enriched, differentiated and accelerated curriculum and learning environments. They suggested that there should be practices that would contribute gifted students to gain higher order thinking skills such as critical thinking, questioning and problem solving.

"I wish gifted students would get basic education together with students whose potentials are close to them and education through a different curriculum. Different conditions, learning environments can be established for these children. If my kid will be gifted, I would like her to get an education with a different curriculum with friends that are similar to her and with an understanding teacher." P8

"Gifted students should be provided opportunities to be creative. This can take one or two hours a week. It can be something like thinking hours or thinking workshops. Also, the teacher should have the required motivation to put forward something creative." P1

High-achieving adults stated that they needed quality teachers and administrators throughout their educational lives. They told that it would improve the quality of the education if the teachers improved their skills, if they were open to using 
technology, and if they were open to communication instead of having an authoritative attitude.

"I wish gifted students would have education with teachers who have enough interest, care, and patience to direct the students to explore instead of just teaching. Also would receive education enriched with different social activities, without any limitations." P3

"I wish our teachers and administrators had not been so authoritative and thus we had had healthier communication with them. Although I personally did not have such an experience, I wish hard work had been taught with affirmation and love instead of violence and humiliation." P4

"I wish I had received education at schools where the learning environment allowed more student participation, students were encouraged to talk more, and students were supported to express their ideas freely." P5

"It is necessary to make the most use of technology, and important to combine it with daily life. I strongly suggest that schools educate students with such a hybrid approach. For instance, I personally wish that these animations created on a computer or various other applications had physical extensions. An approach that combines life and technology can have a very strong effect on children." P1

High-achieving adults suggested that society should be enlightened about those gifted students.

"I wish gifted students would live in a society where they would not be forced or directed to study at a department which would not make them happy." P3

"Perhaps the society should be informed more about gifted students or those students with high potentials." P8

When the opinions of high-achieving adults are examined, the expectations that come forward include high quality curriculum, rich learning environments, competent teachers, administrators that are open to communication, and a conscious society. High-achieving adults think that when these conditions are met, gifted students can reach educational services that are suitable for their needs.

\section{Discussion, Conclusion and Suggestions}

In this study, high-achieving adults' opinions about their educational lives, the problems they faced with and their suggestions to present more qualified educational services to high achieving students have been investigated. The prior aim of educating gifted people is to maintain that students can improve themselves in areas where they have a high potential (Renzulli, 2012). Some of the gifted people can have difficulty in realizing their potentials. They may not always reach the opportunities to realize 
their potentials during their career, because of difficulties such as economic problems they face, insufficient time and not being accepted by the society (Isaacs, 1961; Rinn and Bishop, 2015). When the findings are examined, it has been concluded that highachieving adults had some difficulties to realize their potentials, because of insufficiency of possibilities and teachers, and numerous alterations caused by employment policies of their teachers. Therefore, it is necessary to take precautions to improve our educational system and not to lose high potentials just because of impossibilities.

Students who display enough effort and commitment, need new, challenging and more advanced ideas and concepts, and they need to be supported to develop their talents (Clark, 1997; Subotnik, Olszewski-Kubilius, and Worrell, 2011). It has been found out that almost all of the high-achieving adults who have been interviewed in this study could not go through qualified learning processes they needed; their interests and potentials were ignored as they were at a higher level than the rest of the class and their teachers rendered educational services suitable for an average student in the class. It is important to present differentiated learning experiences to gifted students starting from early childhood in order to ensure optimal development in areas where they have high-performance capacities (Siegle and McCoach, 2010). Moreover, if the students are educated and directed considering their interests and talents, their passion to learn will certainly increase (Sytsma, 2001). As a result, the more individual needs and development of students are considered, the more the quality of the educational services will increase. Hong, Greene, and Hartzell (2011) emphasized that it is necessary for effective teachers to make use of appropriate teaching strategies and technologies aligned with the goal of education, to be aware of the individual qualities of their students and make use of these qualities in teaching processes. Therefore, making use of differentiation, enrichment and acceleration in teaching and learning processes of high achieving students will increase the quality of the educational services as well as the possibility of high achieving students to realize their potentials at the highest level.

According to the high-achieving adults, teachers mostly do not have enough information and experience about high achieving students. Park and Steve Oliver (2009) states that the teachers of gifted students should have strong pedagogical content knowledge in order to provide enriched subject matter knowledge meeting students' pedagogical needs. According to Rosemarin (2014), the teachers of gifted students should be able to understand the thinking ways of their students, be knowledgeable enough to challenge these students, direct them to the learning they need, and have a strong emotional intelligence. However, it has been found out in this study that their teachers had an uncaring attitude towards the profession of teaching and the students. They stated their teachers sometimes damaged their academic selfconfidence and did not act justly. However, according to Gomez-Arizaga, ConejerosSolar, and Martin (2016) gifted students need teachers who consider their past knowledge and ideas. If the teachers are aware of their students' feelings, respect their 
students' previous period of life, talents and different ways of thinking and have the skill of empathy, then the students can turn into independent learners.

Weak educational guidance mostly causes students to waste their time and energy in the wrong ways. Sometimes, gifted students waste most of their time and energy on struggling with the educational system, and their teachers who should support their improvement indeed (Freeman, 2006). Weber and Stanley (2012) express that teachers and administrators often need counseling support for serving gifted students. The interviewed high-achieving adults stated that they could not get the necessary support and guidance they needed from the administrators because of their authoritative attitude together with communication barriers. Aligned with this finding, it is deemed important to raise awareness of the administrators about high achieving students and the guidance services they need. It is necessary for the administrators to establish healthy communication and to ensure supportive services to high achieving students.

Gifted individuals experience conflicts with authoritarian figures, compete with siblings and peers, and display emotional reactions very deeply and intensely as they generally have an idealistic characteristic about social and moral issues (Beljan, Webb, Amend, Web, Goerss and Olenchak, 2006). Their inner conflicts and worries that arise from being a gifted person can cause them to have conflicts with family or friends at school and work (Grobman, 2009). Similarly, the interviewed highachieving adults had problems due to being fair, oversensitive, over-emotional or critical. They stated that they even experienced bullying and peer pressure because of being more successful than others. Moreover, they complained about not having been together with students who were at their level and with whom they could share common areas of interest. Likewise, Willings (1985) underlined gifted students' need to interact with students at their level. In this context, the teachers, administrators and families of high achieving students should learn more about these students' attributes and needs, take the necessary precautions for oversensitiveness and emotional reactions resulting from giftedness, and support their psychological well-being and help them establish a healthy communication with peers.

Gifted students have special needs, so their unique worlds, behaviours and reactions should be understood by the people around them (Lapidot-Berman and Oshrat, 2009). Rotigel (2003) states that many parents of gifted students have very restricted knowledge of giftedness, and grow fear based on stereotypes they have heard. Mirman (1971) emphasized the fact that the society should be aware of the needs of gifted students and a healthy communication should be established with these students. On the other hand, Glass (2004) stated that high level of mental talent may not be understood by the society. The interviewed high-achieving adults who have participated in this study stated that their families and the society could not understand their needs, qualities and expectations, and similarly, they had problems about understanding the society as well. Because of this reason, the awareness of the society 
should be raised about high achieving students, and thus the relation between the society and high achieving people can be constructed vigorously.

Gottfried, Cook, Gottfried, and Morris (2005) emphasized that gifted students' motivation has a great effect on their academic success and career. Mirman (1971) stated that gifted students at state schools can either be unsuccessful because of lacking the necessary support, or they can overcome the barriers and limits of the school and be successful by means of their motivation. The high-achieving adults who participated in this study stated that they could be successful despite the limitations of the school, lacking a role model and having problems with their families and society. The participants did not give up owing to their motivation and could overcome the hardships they faced during their educational lives. Therefore, it is crucial to take the necessary precautions, develop and implement the necessary educational policies in order not to misplace or fail the high potentials because of the limitations of the school, and disregard of families and society.

Expectations and suggestions of the participant high-achieving adults include issues, primarily focus on teachers, then improving the quality of the units of the educational system and meeting the interests and needs of students. VanTassel-Baska (2013) suggests that gifted students should receive education with a flexible but integrated curriculum that is suitable to their talents, and they should get the guidance services they need. Heller (2005) also emphasized the importance of differentiated curriculum and instructional strategies to meet the individual learning needs of gifted students. The sustainability of academic development depends on establishing a strong academic infrastructure especially at early ages when the development of the brain is very fast (Reis and Renzulli, 2009). If gifted students' needs and interests are met starting from their early childhood, and if they reach high quality integrated or enriched curriculum and differentiated instruction, they undoubtedly realize their potentials. Tao (1986) also emphasized the families' importance on guiding their children to reach the most appropriate programs and curriculum fitting their special and unique needs.

The high-achieving adults who were interviewed have been successful despite all the limitations of the education system and inadequate community support. They suggested that the awareness of families and society about high achieving students should be raised, and an effective relation and communication should be established among all the shareholders in order to ensure that gifted students can receive a more effective education. They emphasized the importance of improving the quality of all components in education considering students' interests and needs. If the education is not differentiated aligned with the needs of gifted students, if the family and work environment are not supportive, the problems of these people can be misinterpreted and misdiagnosed (Beljan et al., 2006). It is deemed to be important that policymakers take precautions and develop policies to raise awareness of families and society. Educational policies should be developed aligned with the foundations of Turkish education and effective practices all over the world, teacher training programs and 
high quality curriculums should be developed and enriched learning environments should be established in this regard. Based on the results of the research, it may be suggested to carry out longitudinal studies that start from preschool periods and include adulthood of high achieving people. In addition to qualitative researches, various quantitative researches might be conducted on high-achieving adults. Due to the insufficient identification services in Turkey in the past, the study group to be consisting of some unidentified gifted adults can be considered as a limitation of the study. The age range of the study group can be accepted as a limitation of the study since the educational system and services differ.

\section{Ethical Committee Approval}

The ethical committee approval was obtained from Hacettepe University Ethical Committee, No: 76942594-900/2774, Date: 03.08.2015.

\section{References}

Beljan, P., Webb, J. T., Amend, E. R., Web, N. E., Goerss, J., and Olenchak, F. R. (2006). Misdiagnosis and dual diagnoses of gifted children and adults: ADHD, bipolar, OCD, Asperger's, depression, and other disorders. Gifted and Talented International, 21(2), 83-86. doi: 10.1080/15332276.2006.11673478

Brown, M., Peterson, E. R., and Rawlinson, C. (2020). Research with gifted adults: What international experts think needs to happen to move the field forward. Roeper Review, 42(2), 95-108. doi: 10.1080/02783193.2020.1728797

Clark, B. (1997). Social ideologies and gifted education in today's schools. Peabody Journal of Education, 72(3-4), 81-100. doi: 10.1080/0161956X.1997.9681867

Colangelo, N., Assouline, S., and Gross, M. (Eds.). (2004). A nation deceived: How schools hold back America's brightest students. Iowa City, IA: The University of Iowa.

Çitil, M. (2018). Türkiye'de üstün yeteneklilerin eğitimi politikalarinin değerlendirilmesi. Milli Eğitim Dergisi. $47(1) . \quad 143-172$. https://dergipark.org.tr/tr/pub/milliegitim/issue/40518/480017

Fraenkel, J. R., and Wallen, N. E. (2003). How to design and evaluate research in education. New York: NY. McGraw-Hill Higher Education.

Freeman, J. (2001). Giftedness, responsibility and schools. Gifted Education International, 15(2), 141-150. doi: 10.1177/026142940101500204

Freeman, J. (2006). Giftedness in the long term. Journal for the Education of the Gifted, 29(4), 384-403. doi: 10.4219/jeg-2006-246

Gallagher, J. J. (1997). Least restrictive environment and gifted students. Peabody Journal of Education, 72(3-4), 153-165. doi: 10.1080/0161956X.1997.9681871 
Glass, T. F. (2004). What gift?: The reality of the student who is gifted and talented in public school classrooms. Gifted Child Today, 27(4), 25-29. doi: 10.4219/gct2004-152

Gomez-Arizaga, M. P., Conejeros-Solar, M. L., and Martin, A. (2016). How good is good enough? A community-based assessment of teacher competencies for gifted students. SAGE Open, 6(4), 1-14. doi: 10.1177/2158244016680687

Gottfried, A. W., Cook, C. R., Gottfried, A. E., and Morris, P. E. (2005). Educational characteristics of adolescents with gifted academic intrinsic motivation: A longitudinal investigation from school entry through early adulthood. Gifted Child Quarterly, 49(2), 172-186. doi: 10.1177/001698620504900206

Grobman, J. (2009). A psychodynamic psychotherapy approach to the emotional problems of exceptionally and profoundly gifted adolescents and adults: A psychiatrist's experience. Journal for the Education of the Gifted, 33(1), 106125. doi: 10.1177/016235320903300105

Hastorf, A. H. (1997). Lewis Terman's longitudinal study of the intellectually gifted: early research, recent investigations and the future, Gifted and Talented International, 12(1), 3-7. doi: 10.1080/15332276.1997.11672858

Heller, K. A. (2005). Education and counseling of the gifted and talented in Germany. International Journal for the Advancement of Counselling, 27(2), 191-210. doi: 10.1007/s10447-005-3181-7

Hertzog, N. B. (2003). Impact of gifted programs from the students' perspectives. Gifted Child Quarterly, 47(2), 131-143. doi: 10.1177/001698620304700204

Hertzog, N. B., and Bennett, T. (2004). In whose eyes? Parents' perspectives on the learning needs of their gifted children. Roeper Review, 26(2), 96-104. doi: $10.1080 / 02783190409554249$

Hong, E., Greene, M., and Hartzell, S. (2011). Cognitive and motivational characteristics of elementary teachers in general education classrooms and in gifted programs. Gifted Child Quarterly, 55(4), 250-264. doi: $10.1177 / 0016986211418107$

Isaacs, A. F. (1961). Sources of motivation in creatively gifted adults. Gifted Child Quarterly, 5(2), 63-64. doi: 10.1177/001698626100500208

Koshy, V., Smith, C. P., and Casey, R. (2018). England policy in gifted education: Current problems and promising directions. Gifted Child Today, 41(2), 75-80. doi: $10.1177 / 1076217517750700$

Kronborg, L. (2018). Gifted education in Australia and New Zealand. In S. I. Pfeiffer, E. Shaunessy-Dedrick, and M. Foley-Nicpon (Eds.), APA handbook of giftedness and talent (p. 85-96). American Psychological Association. doi: 10.1037/0000038-006 
Lapidot-Berman, J., and Oshrat, Z. (2009). Sibling relationships in families with gifted children. Gifted Education International, 25(1), 36-47. doi: 10.1177/026142940902500106

Lee, S., Olszewski-Kubilius, P., and Peternel, P. (2010). Achievement after participation in a preparatory program for verbally talented students. Roeper Review, 32(3), 150-163. doi: 10.1080/02783193.2010.485301

Miles, M. B., and Huberman, M. (1994). Qualitative data analysis. Thousand Oaks: Sage.

Mirman, A. M. (1971). Two young gifted adults view the white house conference on youth. Gifted Child Quarterly, 15(2), 91-92. doi: 10.1177/001698627101500207

Park, S., and Steve Oliver, J. (2009). The translation of teachers' understanding of gifted students into instructional strategies for teaching science. Journal of Science Teacher Education, 20(4), 333-351. doi: 10.1007/s10972-009-9138-7

Patton, M. Q. (1990). Qualitative evaluation and research methods. Newbury Park: SAGE Publications, Inc.

Reid, E. (2015). Development of gifted education and an overview of gifted education in the USA, Canada, Equator and México. Slavonic Pedagogical Studies Journal, 4(2), 241-247. doi: 10.18355/PG.2015.4.2.241-247

Reis, S. M., and Renzulli, J. S. (2009). Myth 1: The gifted and talented constitute one single homogeneous group and giftedness is a way of being that stays in the person over time and experiences. Gifted Child Quarterly, 53(4), 233-235. doi: $10.1177 / 0016986209346824$

Renzulli, J. S. (2012). Reexamining the role of gifted education and talent development for the 21st century: A four-part theoretical approach. Gifted Child Quarterly, 56(3), 150-159. doi: 10.1177/0016986212444901

Rinn, A. N., and Bishop, J. (2015). Gifted adults: A systematic review and analysis of the literature. Gifted Child Quarterly, 59(4), 213-235. doi: $10.1177 / 0016986215600795$

Rosemarin, S. (2014). Should the teacher of the gifted be gifted? Gifted Education International, 30(3), 263-270. doi: 10.1177/0261429413486577

Rotigel, J. V. (2003). Understanding the young gifted child: Guidelines for parents, families, and educators. Early Childhood Education Journal, 30(4), 209-214. doi: 10.1023/A:1023331422963

Sak, U., Ayas, M. B., Sezerel, B. B., Öpengin, E., Özdemir, N. N., and Gürbüz, S. D. (2015). Gifted and talented education in Turkey: Critics and prospects/Türkiye'de üstün yeteneklilerin eğitiminin eleştirel bir değerlendirmesi. Türk Üstün Zekâ ve Eğitim Dergisi, 5(2), 110-132. https://dergipark.org.tr/en/download/article-file/1476066 
Siegle, D., and McCoach, D. B. (2010). The first word: A letter from the co-editors: Redefining giftedness. Journal of Advanced Academics, 22(1), 5-9. doi: $10.1177 / 1932202 X 1002200101$

Subotnik, R. F., Olszewski-Kubilius, P., and Worrell, F. C. (2011). Rethinking giftedness and gifted education: A proposed direction forward based on psychological science. Psychological Science in the Public Interest, 12(1), 3-54. doi: $10.1177 / 1529100611418056$

Swanson, J. D. (1997, March). Principals' perspectives on factors which facilitate and block powerful learning. Paper presented at the Annual Meeting of the American Educational Research Association, Chicago, IL.

Sytsma, R. E. (2001). Changing states of matter: science, education, and giftedness in 21 st century high schools. Journal of Secondary Gifted Education, 12(3), 181184. doi: 10.4219/jsge-2001-658

Szymanski, T., and Shaff, T. (2013). Teacher perspectives regarding gifted diverse students. Gifted Children, 6(1), 1.

Tao, B. (1986). Parental involvement in gifted education. Educational Studies in Mathematics, 17(3), 313-321. http://www.jstor.org/stable/3482231

Türkiye Büyük Millet Meclisi (2012). Üstün yetenekli çocukların keşfi, eğitimleriyle ilgili sorunların tespiti ve ülkemizin gelişimine katkı sağlayacak etkin istihdamlarının sağlanması amacıyla kurulan meclis araştırma komisyonu raporu.

https://orgm.meb.gov.tr/meb_iys_dosyalar/2013_03/28093628_trkiyebykmillet meclisiraporu.pdf adresinden erişilmiştir.

Umar, Ç. N. ve Reis, Z. A. (2014). Karma öğrenme yöntemi ile farklılaştırılmış öğretim ortamının üstün zekâlı ve yetenekli öğrencilerin akademik başarılarına etkisi. $\quad \dot{I} \ddot{U} \quad$ Sosyal Bilimler Dergisi, $3(5), \quad$ 1-30. https://openaccess.izu.edu.tr/xmlui/handle/20.500.12436/158

VanTassel-Baska, J. (2013). Curriculum for the gifted: a commitment to excellence. Gifted Child Today, 36(3), 213-214. doi: 10.1177/1076217513487351

Weber, C. L., and Stanley, L. (2012). Educating parents of gifted children: Designing effective workshops for changing parent perceptions. Gifted Child Today, 35(2), 128-136. doi: 10.1177/1076217512437734

Willings, D. (1985). The gifted at university. Gifted Education International, 3(1), 24-31. doi: 10.1177/026142948500300105

Yıldırım, A. ve Şimşek, H. (2011). Sosyal bilimlerde nitel araştırma yöntemleri. Ankara: Seçkin Yayıncılık.

Young, M. H., and Balli, S. J. (2014). Gifted and Talented Education (GATE) student and parent perspectives. Gifted Child Today, 37(4), 236-246. doi: $10.1177 / 1076217514544030$ 


\title{
Yüksek Başarılı Yetişsinlerin Eğitim Yaşantılarına Yönelik Görüşleri ve Üstün Yeteneklilerin Eğitimine
} İlişkin Önerileri ${ }^{1}$

\begin{tabular}{cccc}
\hline MAKALE TÜRÜ & Başvuru Tarihi & Kabul Tarihi & Yayım Tarihi \\
Araştırma Makalesi & 18.03 .2021 & 18.11 .2021 & 30.11 .2021 \\
\hline
\end{tabular}

\author{
Abdul Samet Demirkaya (iD) ${ }^{2}$ \\ Burdur Mehmet Akif Ersoy Üniversitesi \\ Özlenen Özdiyar Gedik (D) ${ }^{3}$ ve Eda Gürlen (iD ${ }^{4}$ \\ Hacettepe Üniversitesi
}

\begin{abstract}
Öz
Araștırmanın amacı, yüksek başarılı yetișkin bireylerin eğitim yaşamlarına yönelik görüşleri ve önerileri doğrultusunda üstün yetenekli öğrencilere sunulan eğitim hizmetlerinin niteliğinin artırılmasına ilişkin öneriler geliştirmektir. Araştırma kapsamında, yüksek başarılı yetişkinlerin eğitim yaşantıları ve karşılaştıkları sorunlara yönelik görüşleri ve üstün yetenekli öğrencilere sunulması gereken eğitim hizmetlerine ilişkin önerileri alınmıştır. Araştırma verileri, olgubilimsel desen çerçevesinde elde edilmiştir. Çalışma grubu, yüksek başarılı sekiz yetişkin bireyden oluşmaktadır. Araştırma verileri yarı yapılandırılmış görüşme formu aracılığıyla toplanmıştır. Verilerin analizinde içerik analizi kullanılmıştır. Sonuç olarak, yüksek başarılı yetişkin bireylerin, potansiyellerini gerçekleştirmeleri için yöneticilerinden, öğretmenlerinden, ailelerinden ve çevrelerinden gerekli destek ve rehberlik hizmetlerini alamadıkları, aileleri ve toplum ile çatışmalar yaşadıkları ve eğitim sisteminin sınırılıkları ile mücadele etmek durumunda kaldıkları belirlenmiştir. Eğitim sistem ve ortamlarının sınırlılıkları, rol model eksikliği, aile ve toplumla yaşadıkları sorunlara karşın zorluklarla başa çıkıp başarılı olabildiklerini belirtmişlerdir. Yüksek başarılı yetişkin bireyler, üstün yetenekli öğrencilerin daha nitelikli eğitim hizmetlerine ulaşabilmeleri için öğretmenlerin ve eğitim sisteminin diğer öğelerinin daha nitelikli duruma getirilmesi, aile ve toplumun bilinçlendirilmesini önermektelerdir.
\end{abstract}

Anahtar sözcükler: Üstün yetenekliler eğitimi, yüksek başarılı yetişkin, üstün yetenekli öğrenci, eğitsel gereksinimler, üstün yeteneklilerin sorunları.

Etik kurul kararı: Bu çalışma, Hacettepe Üniversitesi etik kurul onayı (No: 76942594 900/2774, Tarih: 03.08.2015) ile yapılmıştır.

${ }^{1} \mathrm{Bu}$ çalışma SAY-2015-5069 nolu Hacettepe Üniversitesi Bilimsel Araştırmalar Birimi "Üstün Yeteneklilere Yönelik İlkokul (1-4. sınıf) Öğretim Programı Geliştirme: Bir Eylem Araştırması" başlıklı Araştırma Altyapı Projesi kapsamında gerçekleștirilen çalışmalardan biridir ve çalışmanın bir kısmı "Üstün Yetenekli Yetişkin Bireylerin Eğitim Yaşantılarına İlişkin Görüşleri ve Üstün Yeteneklilerin Eğitimine İlişkin Öneriler” ismiyle Uluslararası Üstün Yetenekliler/ Zekalılar Konferansı., 4-6 Mayıs 2017 tarihinde sözlü bildiri olarak sunulmuştur.

${ }^{2}$ Sorumlu yazar: Arş. Gör., Eğitim Fakültesi, Eğitim Bilimleri Bölümü, Burdur, e-posta: sdemirkaya@ mehmetakif.edu.tr, https://orcid.org/0000-0001-6704-3898

${ }^{3}$ Arş. Gör, Eğitim Fakültesi, Eğitim Bilimleri Bölümü, Ankara, e-posta: ozlenen@ @acettepe.edu.tr, https://orcid.org/0000-0001-5804-6384

${ }^{4}$ Prof. Dr., Eğitim Fakültesi, Eğitim Bilimleri Bölümü, Ankara, e-posta: edaerdem@ @acettepe.edu.tr, https://orcid.org/0000-0002-1719-9840 


\section{Amaç ve Önem}

Dünya, kendileri ve başkaları için sorumluluk alabilecek ve bu sorumluluğun üstesinden gelebilecek üstün yetenekli, iyi eğitimli ve merhametli insanlara daima gereksinim duyacaktır (Freeman, 2001). Üstün yetenekli bireyler, merak, bilgi birikimi, hızlı öğrenme yeteneği, derinlemesine düşünme, yaratıcılık ve özgünlük açısından akranlarından ayrışırlar (Gallagher, 1997; Renzulli, 2012). Dolayısıyla bu bireylerin sahip olduğu üstün potansiyel, hem kendileri hem de toplum açısından büyük önem taşımaktadır.

Türkiye'de yüksek potansiyelli bireyler yetiştirme konusundaki kamuoyu farkındalığı gün geçtikçe artmakta ve bu bireylerin yetiştirilmesine yönelik eğitim politika ve uygulamaları öncelikli konular arasında yer almaktadır (Sak, Ayas, Sezerel, Öpengin, Özdemir ve Gürbüz, 2015). Üstün yetenekli öğrencilere daha nitelikli öğretim hizmetleri sağlanabilmesi için, gereksinimler doğrultusunda gerekli eğitim politikaları ve uygulamaları geliştirilmeli ayrıca eğitim paydaşlarının görüş ve önerileri doğrultusunda gerekli düzenlemelerin yapılması da önemli görülmektedir. Örgün eğitim süreçlerini tamamlamış yüksek başarılı yetişkin bireyler, öğrencilik yaşamları boyunca dahil oldukları eğitim sistemi, okul ortamları, eğitim programları ve öğrenme yaşantıları sonucu sahip oldukları deneyimler nedeniyle önemli bir veri kaynağı oluşturmaktadır. Bu bağlamda araştırmanın amacı, yüksek başarılı yetişkin bireylerin eğitim yaşamlarına yönelik görüşleri ve önerilerini dikkate alarak üstün yetenekli öğrencilere yönelik öğretim hizmetinin niteliğinin artırılmasına ilişkin öneriler geliştirmektir. Bu amaçla yüksek başarılı yetişkin bireylerin okul deneyimleri ve gereksinimleri doğrultusunda eğitim alma durumlarına ilişkin görüşleri alınmıştır. Araştırma sonuçlarının, üstün yetenekli öğrencilere sağlanan eğitim hizmetlerinin niteliğini artırma açısından katkı getirmesi ve elde edilen bulgular doğrultusunda bu özel öğrenci grubunun eğitim süreçlerinde karşılaştığı sorunlara yönelik farkındalığın artırılması umulmaktadır.

\section{Yöntem}

Araştırma verileri, olgubilimsel desen çerçevesinde elde edilmiştir. Olgubilim araştırmaları, belirlenen olgunun ayrıntılı bir şekilde tanınması ve anlaşılması, bu olguya ilişkin derinlemesine örnekler, açıklamalar ve yaşantılara ulaşılmasına olanak sağlar (Yıldırım ve Şimşek, 2011). Araştırmanın çalışma grubunun belirlenmesinde kartopu örnekleme yöntemi kullanılmıştır. Araştırmaya dahil edilen yüksek başarılı yetişkin bireyleri belirlemek için ilgili kurum (Türk Zeka Vakfi vb.) ve uzman kişilere ulaşılmış, katılımcılar öneriler doğrultusunda belirlenmiştir. Çalışma grubu, yaşları 24 ile 60 arasında değişen sekiz yüksek başarılı yetişkin bireyden oluşmaktadır. Çalışma grubunu oluşturan yüksek başarılı yetişkin bireylerden ikisi uzman doktor, ikisi akademisyen, biri yüksek mühendis, biri müzisyen, biri Matematik alanında Zeka Olimpiyatları hakemi, biri de siyasetçi, yazar ve vakıf yöneticisidir. Araştırma verileri, araştırmacılar tarafından geliştirilen yarı yapılandırılmış görüşme formu ile elde edilmiştir. Geliştirilen görüşme formlarının geçerliğinin belirlenmesi amacıyla Eğitim Bilimleri alanında yedi alan uzmanının görüşüne başvurulmuştur. Uzman 
görüşleri doğrultusunda, görüşme formları üzerinde gerekli görülen düzenlemeler yapılmıştır. Araştırmanın geçerlik ve güvenirliğini artırmak için görüşmeler yüz yüze, katılımcıların istedikleri ortamlarda yürütülmüş̧ür. Araştırma kapsamında elde edilen verilerin analizinde nitel araştırma yöntemlerinden içerik analizi yöntemi kullanılmıştır. Kodlayıcılar arası tutarlılık katsayısıyı \%87 olarak belirlenmiştir.

\section{Bulgular}

Görüşmeler sonucunda elde edilen bulgular incelendiğinde; öğretme-öğrenme süreçlerinde karşılaşılan, eğitim sisteminden/eğitim politikalarından, öğretmenlerden, yöneticilerden, diğer öğrencilerden, aile ile toplumdan ve kişisel özelliklerinden kaynaklanan sorunlar olmak üzere yedi tema belirlenmiştir. Buna ek olarak yüksek başarılı yetişkin bireylerin, üstün yetenekli öğrencilerin eğitimine ilişkin beklentileri ve önerilerinin yer aldığ 1 bir tema oluşturulmuştur.

Yüksek başarıll yetişkin bireylerin görüşleri incelendiğinde, olanakların ve üstün yetenekli öğrencilere yönelik öğretim programları ve öğretmen istihdamı yetersizliği gibi eğitim sistemi ve politikalarından kaynaklanan sorunların yaşandığ 1 görülmektedir. Yüksek başarılı yetişkin bireyler, eğitim süreçleri boyunca, ilgi ve gereksinimlerinin dikkate alınmama, uygun güçlük düzeyinde öğretim yaşantılarına ulaşamama, sınıf ortamında göz ardı edilme gibi sorunlar yaşadıklarını dile getirmişlerdir.

Yüksek başarıll yetişkin bireylerin görüşleri incelendiğinde, öğretmenlerin üstün yetenekli öğrencilerin özellikleri, gereksinimleri, eğitimleri ve yönlendirilmesi hakkında çoğu zaman yeterli bilgi ve beceriye sahip olmamakla birlikte mesleğe ve öğrencilere yönelik ilgisiz tutumlar ortaya koydukları belirlenmiştir. Yüksek başarılı yetişkin bireylerden bazılarının, öğretmenlerin öğrenciler arasında ayrımcılık yaptıklarını, öğrencilerin akademik özgüvenlerini zedeleyebilecek davranışlar sergilediğini belirttikleri görülmektedir. Yöneticilerin ise otoriter tutumları nedeniyle iletişim engellerine neden oldukları ve öğrencilerin gereksinim duydukları rehberlik hizmetlerine ulaşmaları noktasında engel oluşturduklarına ilişkin görüşler ile karşılaşılmıştır.

Yüksek başarılı yetişkin bireylerin görüşleri incelendiğinde, eğitim yaşamları boyunca, eğitim ortamlarını paylaştıkları diğer öğrenciler ile başarı düzeyleri arasında farklar olması nedeni ile derse katılımlarının engellenmesi ya da ilgi alanlarını paylaşan öğrencilerin olmaması ile birlikte akran zorbalığı gibi sorunlar yaşadıkları belirlenmiştir. Yüksek başarılı yetişkin bireylerin, ailelerin ve toplumun, gereksinimlerini, özelliklerini ve beklentilerini anlayamadığı, aynı şekilde onların da toplumu anlamada ve beklentilerini karşılamada sorunlar yaşadıklarını ya da toplumda uygun rol modellere ulaşmakta güçlük çektiklerini belirttikleri görülmektedir. Yüksek başarılı yetişkin bireylerin ayrıca aşırı duyarlık, duygusallık, adaletin sağlanmasını isteme ve adaletsizliğe tahammül edememe, aşırı kuralcılığ anlayamama ve kuralları esnetme isteği gibi sorunlar nedeniyle zaman zaman toplumdan uzaklaşma ve pes etme gibi daha ciddi sorunlar yaşadıklarını belirttikleri görülmektedir. 
Yüksek başarılı yetişkin bireyler üstün yetenekli öğrencilere daha iyi eğitim hizmetleri sağlanabilmesi için nitelikli öğretmenler, iletişime açık yöneticiler, nitelikli öğretim programları, etkili rehberlik hizmetleri ve zenginleştirilmiş öğrenme ortamları sunulması ve bilinçli bir toplum oluşturulmasını önermektedir.

\section{Tartıșma, Sonuç ve Öneriler}

$\mathrm{Bu}$ araştırmada, yüksek başarılı yetişkin bireylerin eğitim süreçlerine yönelik görüşleri, karşılaştıkları sorunlar ve üstün yetenekli öğrencilere daha nitelikli öğretim hizmetleri sunulmasına yönelik önerileri belirlenmiştir. Üstün yeteneklilerin eğitiminin öncelikli amacı, öğrencilerin yüksek potansiyele sahip olduğu alanlarda gelişimlerini sağlamaktır (Renzulli, 2012). Üstün yetenekli yetişkin bireylerin bazıları potansiyellerini gerçekleştirmekte zorlanabilir. Kariyerleri boyunca karşılaştıkları ekonomik güçlükler, yetersiz zaman ve toplum tarafindan kabul edilmeme gibi zorluklar nedeni ile her zaman potansiyellerini gerçekleştirebilecekleri olanaklara ulaşamayabilirler (Isaacs, 1961; Rinn ve Bishop, 2015). Araştırma kapsamında yüksek başarılı yetişkin bireylerin, olanakların ve öğretmenlerin yetersizliği, öğretmenlerinin sı sık değişmesi gibi nedenlerden dolayı potansiyellerini gerçekleştirme açısından dönem dönem zorluklar yaşadıkları belirlenmiştir.

Yeterli çaba ve adanmışlık sergileyen öğrenciler yaşlarına bakılmaksızın, uygun güçlük düzeyinde materyal ve kaynaklara, yeni bilgi, düşünce ile kavramlara ve gelişimlerinin desteklenmesine gereksinim duyar (Clark, 1997; Subotnik, OlszewskiKubilius ve Worrell, 2011). Araştırmada görüşlerine başvurulan yüksek başarılı yetişkin bireylerin, eğitim yaşamları boyunca öğretmenlerinin sınıf ortalamasına yönelik eğitim hizmeti sunması nedeniyle gereksinim duydukları nitelikli öğrenme süreçlerine dahil olamadıkları, ilgi ve potansiyellerinin göz ardı edildiği belirlenmiştir. Erken çocukluk döneminden itibaren öğrencilerin yetenekli olduğu alanlarda gelişim sağlamaları için farklılaştıılmış öğrenme yaşantılarının sunulması gereklidir (Siegle ve McCoach, 2010). Öğrenciler, bireysel ilgileri ve yetenekleri göz önünde bulundurularak yetiştirilir ve yönlendirilirse öğrenme tutkuları artar (Sytsma, 2001). Sonuç olarak, öğrencilerin bireysel gereksinimleri ve gelişimlerini göz önünde bulundurmak, öğretim hizmetinin niteliğini artırır.

Araştırma kapsamında görüşlerine başvurulan yüksek başarılı yetişkin bireylere göre öğretmenlerin üstün potansiyelli öğrenciler hakkında yeterli bilgi ve deneyime sahip olmadığı belirlenmiştir. Rosemarin'e (2014) göre üstün yetenekli öğrencilerin öğretmenleri, öğrencilerinin düşünme yollarını anlayabilmeli, onları doyuracak kadar bilgili olmalı, gereksinim duydukları öğrenmelere yönlendirebilmeli ve bu öğretmenlerin duygusal zekası güçlü olmalıdır. Yürütülen araştırmada ise öğretmenlerin, öğretmenlik mesleğine ve öğrencilere ilgisiz tutumlar sergilediği durumlar ile karşılaşılmıştır. Hatta zaman zaman öğrencilerin akademik özgüvenlerini zedeleyebilecek davranışlar sergiledikleri, öğrenciler arasında ayrımcılık yaptıkları belirtilmiştir. Oysa Gomez-Ariazaga, Conejeros-Solar ve Martin'e (2016) göre üstün yetenekli öğrenciler, geçmiş bilgilerini ve düşüncelerini dikkate alan öğretmenlere gereksinim duyar. Öğretmenler, öğrencilerinin yaşadığı duyguları bilir, öğrencilerinin 
geçmişlerine, yeteneklerine ve farklı düşünme biçimlerine saygı duyar, empati becerisine sahip olursa, öğrenciler bağımsız öğrenenler durumuna gelebilirler.

Üstün yetenekli öğrencilerin zaman ve enerjileri genellikle gelişimlerini desteklemesi gereken öğretmenlerle ve eğitim sisteminin diğer bileşenleriyle mücadele etmeye gider (Freeman, 2006). Weber ve Stanley (2012), öğretmenlerin ve yöneticilerin üstün yetenekli öğrencilere hizmet etmek için desteğe gereksinim duyabileceğini belirtmektedir. Araştırma sonucunda da yüksek başarılı yetişkin bireyler, yöneticilerin otoriter tutumları, ilgisiz ve iletişime kapalı olmaları nedeni ile yöneticilerden yeterli desteği görmediklerini ve gereksinim duydukları eğitim ve rehberlik hizmetlerine ulaşamadıklarını belirtmişlerdir.

Üstün yetenekli bireylerin, üstün yeteneklilikten kaynaklanan içsel çatışmaları ve kaygıları, aile, okul ve iş arkadaşları ile çatışmalar yaşamalarına neden olabilir (Grobman, 2009). Zaman zaman kardeş ve akranlarıyla rekabet yaşayabilir, otorite figürleriyle çatışabilir, aşırı duygusal tepkiler gösterebilirler (Beljan ve diğ., 2006). Katılımcıların da benzer şekilde eleştirel bireyler olmaları ve duygusal tepkileri nedeniyle sorunlar yaşadıkları belirlenmiştir. Hatta daha başarılı oldukları için akran baskısına maruz kaldıkları ve akran zorbalığına varan sorunlar yaşadıklarını dile getirmişlerdir. Ayrıca kendi düzeylerinde ve ilgi alanlarını paylaşan öğrencilerle bir arada olamamaktan yakınmışlardır. Benzer şekilde Willings (1985) de üstün yetenekli öğrencilerin, kendi bilişsel düzeylerinde öğrencilerle etkileşime girme gereksiniminde olduğunu vurgulamaktadır.

Üstün yetenekli öğrencilerin özel gereksinimleri vardır, dolayısıyla onların davranış ve tepkilerinin çevreleri tarafından anlaşılması gereklidir (Lapidot-Berman ve Oshrat, 2009). Mirman (1971) toplumun üstün yetenekli öğrencilerin gereksinimlerinin farkında olması, bu öğrencilerle sağlıklı iletişim kurması gereğini vurgulamıştır. Glass (2004) üstün zihinsel yeteneğin, toplum tarafindan anlaşılamayabileceğini belirtmiştir. Araştırmaya katılan yüksek başarılı yetişkin bireyler, ailelerinin ve toplumun, gereksinimlerini, özelliklerini ve beklentilerini anlayamadığını, kendilerinin de toplumu anlamada ve toplumun beklentilerini karşılamada sorunlar yaşadıklarını belirtmişlerdir.

Gottfried, Cook, Gottfried ve Morris (2005) üstün yetenekli öğrencilerin motivasyonlarının akademik başarıları ve kariyerlerinde önemli rol oynadığını vurgulamıştır. Mirman (1971) devlet okullarında üstün yetenekli öğrencilerin ya yeterli desteği göremeyip başarısız olacağını ya da motivasyonları sayesinde sınırlılıkların üstesinden gelip başarılı olacağını dile getirmiştir. Araştırmaya katılan yüksek başarılı yetişkin bireyler ise okulun sınırlılıkları, çevrelerinde rol modeller olmaması, aile ve toplumla yaşadıkları sorunlara karşın, başarılı olabildiklerini belirtmişlerdir. Katılımcılar, yüksek motivasyonları sayesinde pes etmeyip eğitim süreçlerinde karşılaştıkları zorluklarla başa çıkabilmişlerdir.

Görüşlerine başvurulan yüksek başarılı yetişkin bireyler, üstün yetenekli öğrencilerin eğitim hizmetlerinden daha çok verim alabilmesi için öğretmenlerin ve 
eğitim sisteminin diğer öğelerinin daha nitelikli biçime getirilmesi, öğrencilerin ilgi ve gereksinimlerinin karşılanmasını önermektedir. VanTassel-Baska (2013) üstün yetenekli öğrencilerin, esneklik sağlayan bütünleştirilmiş öğretim programları ile yeteneklerine uygun eğitim alması ve nitelikli rehberlik hizmetlerinin sağlanması gereğini vurgulamıştır. Katılımcılar, aile ve toplumun bilinçlendirilmesi ve tüm paydaşlar arasında etkili iletişimin kurulmasını önermişlerdir. Beljan ve diğerleri (2006) eğitim, iş ve aile ortamı desteğinin, bu kişilerin gelişimlerinde ve sorunlarını çözmelerinde büyük önemi olduğunu belirtmektedir. $\mathrm{Bu}$ bağlamda politika yapıcıların, aile ve toplumun bilinçlendirilmesine yönelik önlemler alması üstün yetenekli öğrencilerin potansiyellerini gerçekleştirmeleri açısından önemli görülmektedir.

\section{Etik Kurul Kararı}

Bu çalışma, Hacettepe Üniversitesi etik kurul onayı (No: 76942594-900/2774, Tarih: 03.08.2015) ile yapılmıştır. 